\title{
STOCK MARKET EARNINGS AND ITS IMPACT ON NIGERIAN ECONOMY
}

\author{
ASHAMU Sikiru Oyerinde.(PhD) \\ Department of Banking and Finance, Faculty of Management Sciences, Lagos State University, Ojo, Lagos. \\ Soyerinde2012@gmail.com, +2348033713969 \\ DOI: 10.36108/ljerhrm/8102.01.0191
}

\begin{abstract}
The stock market provides equity and a direct finance to potential investors for purposes of economic growth and development it enhances the efficiency of capital formation and allocation of resources and provides long-term capital for economy. The main objective of the study is to provide empirical evidence of the effect of stock market earnings on Nigeria's economic growth. Hypotheses were set and model designed to fit the variables on equation line. Data were sourced from secondary sources mainly from Nigeria Stock Exchange Fact Book, Security and Exchange Commission Fact Book, National Bureau of Statistics and Central Bank of Nigeria Statistical Bulletin (various editions). The data was collected in annual time-series from 1991 to 2016. It was manipulated using Ordinary Least Square (OLS) Method and Phillip-Perron Unit Root Test using E.View 9.0..From the regression results, it was discovered that Market Capitalization has a positive and significant effect on gross domestic product which is the proxy for economic growth with the probability value of less than 10 percent under 0.05 significant level. It then mean that Nigeria Stock Market activities (as represented by Market capitalization-MC, Price Earnings Ratio-PER and Dividend Yield-DY) has positive influence on economic growth (GDP).Therefore in view of thefindings, it is recommended that there should be improvement in the dealing market capitalization by encouraging more foreign investors to participate in the market, maintain and improve it state of technology like automated trading and settlement practices, electronic fund clearance and eliminate physical transfer of shares.
\end{abstract}

Keywords: Dividend Yield, Financial Intermediation, Johansen Co-integration, Market Capitalization.

\section{Introduction}

Financial institutions play an important role in the mobilization of financial resources for long term investment through the process known as financial intermediation. The existence of money markets facilitate trading in shortterm debt instruments to meet short-term needs of large users of funds such as governments, banks and similar institutions. Government treasury bills and similar securities, as well as company commercial bills, are examples of instruments traded in the money market. A wide range of financial institutions, including merchant banks, commercial banks, the Central Bank and other dealers operate in the money market. Public as well as private sector operators make use of various financial instruments to raise and invest short term funds which, if need be, can be quickly liquidated to satisfy short-term needs. Unlike the money market, the capital market mobilizes longterm debt and equity finance for investments in long-term assets. Capital markets also help to strengthen corporate financial structure and improve the general solvency of the financial system. Stock market is a prominent market for mobilization of both short and long term fund. It provides the bridge through which the savings of surplus units may be transformed into medium and long term investments in the deficits units. These processes enable firms to raise capital by issuing their shares and also where the holders of the shares can trade it (Baker, 2016). All these act as catalyst for each economic sector to grow and contribute to economic growth and development.

The stock market provides equity and a direct form of finance to potential investors for economic purposes. This role enables it to function as a critical long-term lubricant in the economic growth process. The performance of the stock market is in addition often considered an essential or good barometer for measuring a country's economic strength and development. Thus, an economy with an active stock market may have its vital stock market index regularly used as a guide in the measurement of changes in the general level of economic activities within the concerned economy. One other major role of the stock market as an economic institution is that it enhances the efficiency of capital formation and allocation of resources. It is therefore expected that every active stock market will facilitate the availability of long-term capital for economically productive activities and this remains a key requirement for economic growth and development. The stock market also provides a means by which the capital needed for efficient or effective growth in the economy is made available. Stock markets are in addition regarded as a necessary tool for economic growth and development as they provide listed companies the platform to mobilize much needed capital for the long-term investment needs of businesses. This also encourages surplus spending economic agents to save thereby increasing the saving rate as well as directly stimulating more investments and consequently bringing additional investment income to the owners of funds. 
Baumol,(1960), Mun, Siong, and Thing, (2008) posited that there is indeed a linkage between the capital market performance and growth in the economy. Recently a lot of importance has been attached to the importance of stock exchange market in Nigeria. The debate and arguments on the exact role of the Capital markets on economic growth is ongoing and so far, a number of studies have shown conflicting results (Oke and Adeusi, 2012;

Osaze, 2000;Omole, 1997, Osamwonyi, 2005; Osaze, 1995). While some are of the opinion that a negative link exists between Capital markets on economic growth, others argue that there exists a positive link. Summarily, stock market contributed to economic growth in a sustained manner if the right political climate exists. The issues of macroeconomic stability, adequate education and enlightenment of the public on the benefits of stock markets have serious impact on growth and development of any country's economy. It is also of note that minimizing sharp practices of market operators is germane to the full realization of the benefits of the stock market in any given economy. It is of note also that activities of Stock markets are sensitive to national and international events and it react immediately.

The Nigerian stock exchange (NSE) witnessed unprecedented growth in total market capitalization and value of shares traded between 2004 up to the second quarter of 2008. Immediately the crisis was pronounced in July 2008 in USA, the Nigerian stock market started experiencing serious downturn activities. It was also observed that investors were pulling out their resources which made the stock price to generally go down. Both developed and developing economies faced negative repercussions of the financial crisis and experienced adverse impact on their economies via the channel of finance and trade. Net capital inflows shrunk drastically from the beginning of the crisis. This crisis badly affected foreign direct investment, portfolio investment and exports of developing nations (Mun, Siong, and Thing, 2008). The ripple effects of the global financial crisis seem to have had a dramatic negative effect on the Nigerian stock exchange. Market capitalization has been reduced from over N10.18 trillion to $\$ 5.2$ trillion and a market index from 5799 points to 22000 points by October 2009 and a flight of foreign portfolio investment to extent that stock and shares were no longer accepted as collateral (Osaze, 2009).

Stock market has been associated with economic growth through its role as sources for new private capital. On the other hand, economic growth may be the catalyst for stock market growths. According to Osamwonyi (2005), a stock exchange is an arrangement for trading financial securities and where one can raise long-term capital. It seeks the efficient allocation of available capital funds to the diverse uses in the economy and through its extreme sensitive pricing mechanism, ensures that the available capital resources are allocated to firms with competitive returns. Though the use of stock market indicator for the prediction of future economic growth or vice versa has been a debatable issue in finance and economics, it is commonly believed that large decreases in stock prices are reflective of future recession, and increasing stock prices are leading indicators of future economic growth (Mun, Siong \& Thing, 2008).

The rapid expansion of these stock exchanges in the continent has contributed to economic development in various ways such as facilitating long term capital mobilization, the provision of alternative investment opportunities, attracting foreign capital inflows and serving as a signal of economic performance (Osaze, 2007). Well-functioning stock markets, along with well-designed institutions and regulatory systems will foster economic growth. The principal channel for the linkage between stock market development and economic performance is liquidity provision of the market (Levine, 1998), he found out that, stock markets contribute to financing of corporate investments and hence growth of listed firms in Africa as they are required to keep best practices. Most stock markets especially those in the developing countries like Nigeria face constraints liquidity, absence of activities and absence of well-developed investor base.

Hence, the main objective of this study is to X-ray how stock market has contributed to the Nigeria economy. The specific objectives of the study are to:

* Examine how the Nigerian stock market's activities have contributed to economic growth in Nigeria.

* Determine the impact of Nigerian stock market's activities on Nigeria's economic development.

The tentative statements that will guide the research work are formulated in null hypothesis only as thus;

1. Nigeria stock market's activities have not contributed to economic growth in Nigeria.

2. Nigerian stock market's activities have no impact on Nigeria's economic development.

This study intends to bridge this gap between theories of intermediation and practices of fund transmission in Nigeria using Nigerian Stock exchange as a case study, in pursuit of this goal, pertinent questions will be addressed that will of benefit to other Researchers, Scholars, policymakers as well as financial regulators. Furthermore, this study would provide the required clues for governments and economic stakeholders to tackle the financial and economic crisis problems from its root. 
Therefore, the motivation of this study was to empirically analyze the effects of stock market indicators on the growth and development rate of the Nigerian economy. The paper covers the period of 1987 to 2016 which represents the period of grey, boom and doom of capital market development in Nigeria. Within this period, great stripes were made in the infrastructures, institutions and regulations that pertain to the Capital market of Nigeria. The base year for current calculation of the All-share Index in the Nigerian Capital Market is 1985. Thus the period enables us to analyze the effect if any of capital markets volatility on economic growth in the country.

This paper is structured in four (4) sections; Section I is the introduction of the study which shall contain background of the study, the objectives, significance of the study, scope and hypotheses. Section II, consist of review of related literature, conceptual and theoretical framework and development of model. Section III is the research methodology which contains method of data collection and analyses as well as interpretation of results obtained while Section IV contain the Summary of findings, Conclusion and Recommendations.

\section{Literature Review}

Nigerian stock market plays a major role in enhancing the efficiency in capital formation and allocation. It facilitates corporations and the government to raise long-term capital which enables them to finance new projects and expand other existing ones. Andrianaivoand Yartey (2009) observe that the performance of the economy is boosted when there is adequate capital supplied to productive sector of the economic. However as economies continue to develop; additional funds are therefore needed to meet the rapid expansion. Stock market therefore serves as an appropriate tool in the mobilization and allocation of fund among competing uses which are critical to the growth and efficiency of the economy. It is in this light that the stock exchange market acts as a barometer for economic performance. Andrianaivoand Yartey (2009) further argue that the determination of the overall growth of an economy depends on how efficiently the stock market performs in its allocative functions of capital.

The most important of this function is that capital resources are channeled by the mechanism of the forces of demand and supply to those firms with relatively high and increasing productivity thus enhancing economic expansion and growth. Stock markets are a vital component for economic development as they provide listed companies with a platform to raise long-term capital and also provide investors with a forum for investing their surplus funds. Stock markets therefore encourage investors with surplus funds to invest them in additional financial instruments that better matches their liquidity preferences and risk appetite. Better savings mobilization may increase the savings rate, and which in turn spurs investments and earns investment income to the owners of those funds.

As economies develop, more funds are needed to meet the rapid development and the stock markets serve as a veritable tool in the mobilization and allocation of savings among competing uses which are critical to the growth and efficiency of the economy (Baker, 2016). Stock market liquidity again helps to reduce the downside risk and cost of investing in projects that do not pay-off for a longtime. Bae, Bailey, and Mao, (2006), observed that with a liquid market, the initial investors do not lose access to their savings for the duration of their investment project because they can quickly and easily sell their stake in the company. Nigerian stock market is a major component in the financial sector of the country; it serves a pivotal role in contributing towards economic growth.

Stock markets fuel economic growth through diversification, mobilizing and pooling of savings from different investors and availing them to companies for optimal utilization. As much as the stock markets are important in facilitating privatization channels and diversification of the financial sector services, they also provide the listed companies with a platform to raise long-term capital, and also offer the investors alternative investments to put their funds in. However, they face serious constraints if not properly monitored and adequate measures taken to curb any externalities.

\section{Conceptual Framework}

Every economy seeks to promote an effective capital market with the primary objective of mobilizing long-term funds from surplus economic units for the use of the deficit units for investment purposes. Capital market operation reduces over-reliance on the money market, assists in promoting a solvent and competitive financial sector as well as fostering a healthy stock market culture. The impact of capital market on industrial growth in economy is demonstrated in the activities of capital market in the mobilization of funds and their eventual transfer to businesses, the government and individuals that need those funds for investment. 
Capital market is defined as the market where medium to long-term finance can be raised Adelegan, \& Radzewicz-Back, (2009). In another exposition, Daferighe, and Aje(2009) note that capital market is the market for dealings (i.e. lending and borrowing) in longer-term loanable funds. Mun, Siong and Thing (2008) describe it as a forum through which long-term funds are made available by the surplus to the deficit economic units. It must, however, be noted that although all the surplus economic units have access to the capital market, not all the deficit economic units have the same easy access to it. The restriction on the part of the borrowers is meant to enforce the security of the funds provided by the lenders. In order to ensure that lenders are not subjected to undue risks, borrowers in the capital market need to satisfy certain basic requirement, it has very profound implication for socio-economic development of any nation. Companies can finance their operations by raising funds through issuing equity (ownership) or debenture/bond borrowed as securities. Equities have perpetual life while bond/debenture issues are structured to mature in periods of years varying from the medium to the long-term of usually between five and twenty-five years.

Capital market offers access to a variety of financial instruments that enable economic agents to pool, price, and exchange risk. Through assets with attractive yields, liquidity and risk characteristics, it encourages savings in financial form. This is very essential for government and other institutions in need of long-term funds and for suppliers of long-term funds (Okereke-Onyiuke, 2000). Based on its importance in accelerating economic growth and development, government of most nations tends to have keen interest in the performance of its capital market. The concern is for sustained confidence in the market and for a strong investor's protection arrangement. Nigeria Securities and Exchange Commission (NSEC) is the government agency responsible for developing and regulating the Nigeria capital market. It was created by Act No. 71 of 1979 and re-acted as Securities and Exchange Commission Decree No. 29 of 1988. The NSEC purses its objectives by registering all market operators based on capital adequacy, competence and solvency as criteria.

Economic growth is generally agreed to indicate development of an economy, because it transforms a country from a five percent saver to a fifteen percent saver. Thus, it is argued that for capital market to contribute to economic growth and development in Nigeria, it must operate efficiently. Most often, where the market operate efficiently, confidence will be generated in the minds of the public and investors will be willing to part with hard earned funds and invest them in securities with the hope that in future they will recoup their investment. Hence, ability to mobilize funds easily and cheaply in the capital market is a motivation for enterprises to expand their operations and diversify into large-scale enterprises. Therefore, capital market provides financial resources through equity and debt securities, to private sector enterprises (both large and small) and in the process has contributed to the development of the industrial sector.

Stock market plays a fundamental role in providing the secondary market for investors and financial institutions that will be willing to trade their securities. Along with other factors like market size and market capitalization, market liquidity is also considered as one of the best instrument measure efficiency of stock market. Market liquidity is a smoothly and obscure concept since it encourages a number of transactional properties of the market (Mockus, \&Liu, 2012). A liquid market can be characterized as a market where large transactions can be executed without or less impact on security prices (Bekaert, Harvey, \& Lundblad, 2011). According to Bekaert et al. (2011) liquidity can be defined as the ability to make a transaction quickly and with less or no substantially moving prices and Lervine and Zervos (2010) definemarket depth as the ability to make transactions at the ongoing market prices.

Stock exchange or stock market is a market where old securities that have been already issued by the companies to the public are bought and sold through authorized agents according to rules and regulations. It is a mechanism though which the holder of securities may find a buyer for his holdings at a fair price. Similarly buyer of securities may find an immediate seller who is willing to sell his holdings at a fair price. The securities are bought and sold continuously among the investors in these stock exchanges without the involvement of companies. Stock exchanges facilitate the free trade of only the securities that are listed. Omole, (2007) defines stock market as financial establishment, which promotes capital formation and competence in capital allocation. The stock markets also enable the government and private firms to finance its new projects as well as establishing, modernizing and expanding commercial or industrial concerns through raising long term capital. Omole, (2007) argues that capital resources should be provided to industries where such industries have the capacity and capability of increasing its production and productivity. 


\section{Theories of Capital Markets}

\section{Efficient Market Hypothesis}

The efficient-market hypothesis emerged as a prominent theory in the mid-1960s but was first expressed by Louis Bachelier, a French mathematician, in his 1900 dissertation, "The Theory of Speculation". His work was largely ignored until the 1950s when his work along with the empirical studies were published in an anthology edited by Paul Cootner. In 1965 Fama published his dissertation arguing for the random walk hypothesis, and Samuelson published a proof for a version of the efficient-market hypothesis. In 1970, Fama published a review of both the theory and the evidence for the hypothesis. The paper extended and refined the theory, included the definitions for three forms of financial market efficiency: weak, semi-strong and strong.

However beginning in the 30s, independent work supporting his thesis emerged in form of a small number of studies indicated that US stock prices and related financial series followed a random walk model. Research by Alfred Cowles in the '30s and '40s suggested that professional investors were in unable to outperform the market. Empirical analyses have consistently found problems with the efficient-market hypothesis, the most consistent being that stocks with low price to earnings (and similarly, low price to cash-flow or book value) outperform other stocks. Alternative theories have proposed that cognitive biases cause these inefficiencies, leading investors to purchase overpriced growth stocks rather than value stocks though the hypothesis has become controversial because substantial and lasting inefficiencies are observed.

Further to this evidence that the UK stock market is weak-form efficient, other studies of capital markets have pointed toward their being semi-strong-form efficient. A study by Khan of the grain futures market indicated semi-strong form efficiency following the release of large trader position information (Khan, 1986). Studies by Firth (1976, 1979, and 1980) in the United Kingdom have compared the share prices existing after a takeover announcement with the bid offer. Firth found that the share prices were fully and instantaneously adjusted to their correct levels, thus concluding that the UK stock market was semi-strong-form efficient. However, the market's ability to efficiently respond to a short term, widely publicized event such as a takeover announcement does not necessarily prove market efficiency related to other more long term, amorphous factors. David Dreman has criticized the evidence provided by this instant "efficient" response, pointing out that an immediate response is not necessarily efficient, and that the long-term performance of the stock in response to certain movements is better indications. A study on stocks response to dividend cuts or increases over three years found that after an announcement of a dividend cut, stocks underperformed the market by $15.3 \%$ for the three-year period, while stocks outperformed $24.8 \%$ for the three years afterward after a dividend increase announcement

\section{Capital Market Theory}

Forty years have passed since the principles of classical economics were first applied formally to finance through the contributions of Fama in 1970 and his now-renowned fellow academics. Over the intervening years, capital market theory and the efficient market hypothesis have been developed and modified to form an elegant and comprehensive framework for understanding asset pricing and risk. But events have dealt a cruel blow to these theories, as John Authers argued capital market booms and crashes, culminating in the latest sorry and socially costly crisis, have discredited the idea that markets are efficient and that prices reflect fair value.

Some economists still insist these events are simply the lively interplay of broadly efficient markets and see no cause to abandon the prevailing wisdom. Other commentators, including a number of leading economists, have proclaimed the death of mainstream finance theory and all that goes with it, especially the efficient market hypothesis, rational expectations and mathematical modeling. The way forward, they argue, is to understand finance based on behavioural models on the grounds that psychological biases and irrational urges better explain the erratic performance of asset prices and capital markets. Presented this way, the choice seems stark and unsettling, and there is no doubt that the academic interpretation of finance is at a critical juncture. The model explains asset pricing in terms of a battle between fair value and momentum. It shows how rational profit seeking by agents and the investors who appoint them gives rise to mispricing and volatility. Once momentum becomes embedded in markets, agents then logically respond by adopting strategies that are likely to reinforce the trends. Explaining the formation of asset pricing in this way seems to provide a clearer understanding of how and why investors and prices behave as they do. For example, it throws fresh light on why value stocks generally outperform growth stocks despite offering seemingly poorer earnings prospects. The new approach offers a more convincing interpretation of the way stock prices react to earnings announcements or other news. It also shows 
how short-term incentives, such as annual performance fees, cause fund managers to concentrate on highturnover, trend-following strategies that add to the distortions in markets, which are then profitably exploited by long-horizon investors. At the level of national markets and entire asset classes, it will no longer be acceptable to say that competition delivers the right price or that the market exerts self-discipline.

\section{Capital Asset Pricing Model}

Capital Asset Pricing Model (CAPM) is used to determine a theoretically appropriate required rate of return of an asset if that asset is to be added to an already well-diversified portfolio, given that asset's non-diversifiable risk. The model takes into account the asset's sensitivity to non-diversifiable risk (also known as systematic risk or market risk), often represented by the quantity beta $(\beta)$ in the financial industry, as well as the expected return of the market and the expected return of a theoretical risk-free asset. It assumes that the risk-return profile of a portfolio can be optimized - an optimal portfolio displays the lowest possible level of risk for its level of return.

Additionally, since each additional asset introduced into a portfolio further diversifies the portfolio, the optimal portfolio must comprise every asset, (assuming no trading costs) with each asset value-weighted to achieve the above (assuming that any asset is infinitely divisible). All such optimal portfolios, i.e., one for each level of return, comprise the efficient frontier. An investor might choose to invest a proportion of his or her wealth in a portfolio of risky assets with the remainder in cash - earning interest at the risk free rate (or indeed may borrow money to fund his or her purchase of risky assets in which case there is negative cash weighting). Here, the ratio of risky assets to risk free asset does not determine overall return - this relationship is clearly linear. It is thus possible to achieve a particular return in one of two ways, by investing all of one's wealth in a risky portfolio, or by investing a proportion in a risky portfolio and the remainder in cash (either borrowed or invested). For a given level of return, however, only one of these portfolios will be optimal (in the sense of lowest risk). Since the risk free asset is, by definition, uncorrelated with any other asset, option 2 will generally have the lower variance and hence be the more efficient of the two. This relationship also holds for portfolios along the efficient frontier: a higher return portfolio plus cash is more efficient than a lower return portfolio alone for that lower level of return. For a given risk free rate, there is only one optimal portfolio which can be combined with cash to achieve the lowest level of risk for any possible return. This is the market portfolio.

\section{Empirical Framework}

There have been the growing concerns and controversies on the role of the Stock markets on economic growth and development (Lervine, \& Zervos, 2010 and Levine 1996). There have been mixed results; while some are in support of a positive link, some negative link and others do not find any empirical evidence to support such conclusion and the stock market is of interest to economists and policy makers because of the perceived benefits to the economy.

Oyefusi and Mogbolu (2003) also examined the relationship between Nigeria stock market and economic growth during the period $1980-2000$ using ordinary least squares regression (OLS). The result indicated that there is a positive relationship between the stock market and economic growth and suggest the pursuit of policies geared towards rapid development of the stock market. Levine (1991) shows that stock market is positively robustly associated with long-run economic growth. In addition, using cross- country data for 47 countries from Lervine, \& Zervos, (2010) find that stock market liquidity is positively and significantly correlated with current and future rates of economic growth, even after controlling for economic and political factors. They also find that measures of both stock market liquidity and banking development significantly predict future rates of growth. They therefore, conclude that stock markets provide important but different financial services to banks.

Furthermore, using data from 44 industrial and developing countries from 1976 to 1993, Daferighe, and Aje, (2009) investigate the relationships between stock market development and financial intermediary. They find that countries with better-developed stock markets also have better-developed financial intermediaries. Thus, they conclude that stock market development goes hand-in-hand with financial intermediary. Existing models suggest that stock market development is a multifaceted concept, involving issues of market size, liquidity, volatility, concentration, integration with world capital markets, and institutional development. Using data on 44 developed and emerging markets from 1986 to 1993, Daferighe, and Aje, (Op.cit) find that large stock markets are more liquid, less volatile, and more internationally integrated than smaller markets. 
Stock market contributes to economic growth through the specific services it performs either directly or indirectly. Notable among the functions of the stock market are mobilization of savings, creation of liquidity, risk diversification, improved dissemination and acquisition of information, and enhanced incentive for corporate control. Improving the efficiency and effectiveness of these functions, through prompt delivery of their services can augment the rate of economic growth. The capital market mobilizes long term financial resources from surplus economic units to deficit units of the economy (Adelegan, \& Radzewicz-Back, 2009).

Onagoruwa (2006); Daferighe and Aje (2009) look at some of the factors influencing stock market price behavior. The stock market serves as a veritable tool in the mobilization and allocation of savings among competing uses which are critical to the growth and efficiency of the economy.

Billmeier, and Massa, (2007) note that the importance of economic growth is not arguable and spans across disciplines affecting all areas of society directly and indirectly. In addition, macroeconomic policies on factors like interest rates and inflation rates assist in promoting economic growth and also equally important, are vehicles of economic growth such as the stock market. However, a basic proposition of growth theory is that in order to sustain a positive growth rate of output per capita in the long run, there must be constant advances in technological knowledge in the form of new goods, new markets, or new processes. This proposition can be demonstrated using the neoclassical growth model developed by Solow [65], which explains that if there were no technological progress, then the effects of diminishing returns would finally cause economic growth to die down. One of the biggest challenges facing growth economists though, is to identify the fundamental driving forces of growth and explain the great variation in cross country economic performance over time. Neither the neoclassical growth models nor the endogenous growth models have the ability to address adequately the phenomena of uneven development and persistent international inequality.

Understanding the process of economic growth has therefore been termed the ultimate objective of economics and taking on such a quest requires a lot of dedication as even small insights along the way can have major benefits to millions of people, and small mistakes can do the reverse. Therefore, economies 184 Stock market performance and economic growth which achieve large increases in output over extended periods of time, not only enable rapid increases in standards of living, but also have serious changes in the economic, political and social landscape of a nation. Within the endogenous growth literature, Baker, (2016), argues that, a number of theoretical studies have focused on the links between endogenous growth and financial markets. However, Billmeier, and Massa, (2007) and Levine, (1991) were among the first to propose endogenous growth models to identify the channels through which financial markets affect long-run economic growth. The two papers emphasized that financial markets help diversify agents' liquidity and investment risk, attract more savings into productive investment and prevent the premature withdrawal of physical capital invested in the long-term projects.

Consequently, the existence of financial markets means that more capital can be kept in productive investments, which in the end raises the rate of economic growth. King and Levine suggested another approach to identifying the channel of transmission between finance and growth, and in their model they pointed at innovation as the engine of growth, In this aspect, financial markets evaluate the potential innovative projects, finance the most promising ones and monitor the carrying out of investment. This way financial markets help in the function of efficient resource allocation. Therefore, an economy with proper functioning financial markets will experience a higher growth rate of productivity (Oke \& Adeusi, 2012). The link between macroeconomic fundamentals and the equity market is naturally appealing given the importance of macroeconomic variables in determining company cash flows and overall systematic. The dividend discount model (DDM) and the arbitrage pricing theory (APT), on the other hand provide important theoretical frameworks that show the channel through which the behavior of macroeconomic variables are factored into stock prices. These models predict that any anticipated or unanticipated arrival of new information about GDP, production, inflation, interest rates, exchange rates, etc. will alter stock prices/returns through the impact on expected dividends, the discount rate or both(Oke \& Adeusi, 2012).

The fact that expected dividends (or cash flow) and expected discount rate affect current stock prices/returns, it should be logical that the conditional variance of current returns will be a function of conditional variance of expected future cash flow and future discount rate. Baker, (2016) further argued that, since future corporate earnings and thus cash flows are related to the health of the macro economy, it is unsurprising that changes in uncertainty about the future behavior of macroeconomic fundamentals trigger proportional reaction in current volatility of stock returns, assuming a constant discount rate. 


\section{Research Methodology}

The study aims at providing empirical evidence on the effect of stock market earnings on Nigeria economic growth and development. The data were sourced from secondary sources making use of Nigeria Stock Exchange Fact Book, Security and Exchange Commission Fact Book, National Bureau of Statistics and Central Bank of Nigeria Statistical Bulletin. The study employed annual time-series data from 1991 to 2016.

Data collected was manipulated using Ordinary Least Square (OLS) Method and Phillip-Perron Unit Root Test.

\section{Specification of the Empirical Model}

The model is used in this research work is pattern against the model of Lervine, and Zervos, (2010) that established relationship between stock market activities and economic growth, it is modified to measure the impact of the stock market earnings on Nigerian economy.

The model was specifying as follows;

$\mathrm{GDP}=\mathrm{F}(\mathrm{MC}, \mathrm{PER}, \mathrm{DY}, \mathrm{PCI}, \mathrm{INF})$

$\mathrm{GDP}_{\mathrm{t}}=\beta_{0}+\beta_{1} \mathrm{MC}_{\mathrm{t}}+\beta_{2} \mathrm{PER}_{\mathrm{t}}+\beta_{3} \mathrm{DY}_{\mathrm{t}}+\beta_{4} \mathrm{PCI}_{\mathrm{t}}+\beta_{5} \mathrm{INF}+\mathrm{U}_{\mathrm{t}}$

Where:

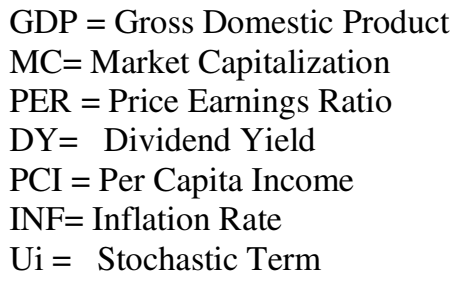

\section{A Prior Expectation}

As earlier stated the variables include Gross Domestic Product which is the proxy for economic growth () taken as the dependent variable, MCAP, DY, PER, PCI, INT and INF which are the independent variables. It is expected that all the explanatory variables except inflation will have a direct positive relationship with the dependent variable. That is a unit increase in any of these variable will lead to an increase in the dependable variable. But INF will have direct negative relationship with economic growth (GDP), that is increase in inflation rate will lead to decrease in economic growth.

This can be expressed mathematical as: $\beta_{1}, \beta_{2}, \beta_{3}, \beta_{4}>0$ while $\beta_{5}<0$.

\section{Analyses and Interpretation of Results}

Analysis of data and interpretation of result are two essential aspect of the study. It is therefore, imperative to conduct thorough analysis with an appropriate technique and interpretation of result. This research work has therefore employed econometrics analysis using Ordinary Least Square (OLS) using computer based statistical package-E-View 9.0. All tests were conducted at 5\% level of significance with 95 percent confidence level.

The model that was designed for this study contained six (6) variables, which are: Gross Domestic Product, Market Capitalization, Price Earnings Ratio, Dividend Yield, Per capita Income and Inflation Rate. GDP is the dependent variable while other variables are independent variables.

In this study two types of data analyses were presented, descriptive analysis and inferential analysis. The descriptive analysis helps to describe the variables and nature and characteristics of the variables, while the inferential analyses provide detailed information about the relationship between the variables under study. The Time Series Data (TSD) will be regressed in other to bring out the parameters under study. 


\section{Descriptive Statistics}

Descriptive statistics of the variables are presented in table below;

\begin{tabular}{|l|c|c|c|c|c|c|}
\hline & GDP & MC & PER & DY & PCI & INF \\
\hline Mean & 4065648. & 673955.1 & 741677.3 & 3414962. & 13.46245 & 16.77094 \\
\hline Median & 69146.99 & 13934.10 & 8897.100 & 37004.20 & 12.50000 & 10.80000 \\
\hline Maximum & 39763890 & 8756845. & 6390528. & 11832679 & 29.80000 & 72.81000 \\
\hline Minimum & 2233.000 & 43.70000 & 82.30000 & -310.3000 & 6.000000 & 2.500000 \\
\hline Std. Dev. & 10111636 & 1896667. & 1496648. & 2617348. & 6.633552 & 16.14007 \\
\hline Skewness & 2.223038 & 2.818878 & 2.622660 & 2.851579 & 0.468613 & 1.918420 \\
\hline Kurtosis & 6.905522 & 10.06372 & 8.807281 & 10.17196 & 2.062297 & 5.810793 \\
\hline Jarque-Bera & 77.33738 & 180.3776 & 135.2337 & 185.4184 & 3.881541 & 49.95669 \\
\hline Probability & 0.000000 & 0.000000 & 0.000000 & 0.000000 & 0.143593 & 0.000000 \\
\hline Sum & $2.67 \mathrm{E}+08$ & 41125621 & 34008896 & 59094020 & 713.5100 & 888.8600 \\
\hline Sum Sq. Dev. & $5.32 \mathrm{E}+15$ & $1.87 \mathrm{E}+14$ & $1.16 \mathrm{E}+14$ & $3.56 \mathrm{E}+14$ & 2288.208 & 13546.09 \\
\hline & & & & & & \\
Observations & $\mathbf{5 3}$ & $\mathbf{5 3}$ & $\mathbf{5 3}$ & $\mathbf{5 3}$ & $\mathbf{5 3}$ & $\mathbf{5 3}$ \\
\hline
\end{tabular}

Source: E-View Version 9.0

The descriptive statistics include mean, median, minimum, maximum, standard deviation and Jarque-Bera statistics for normality test. The descriptive statistics reveal that average value for GDP is 40656.48 percent which is ranging from positive 22.33 percent to 397638.90 percent. Average value for MC, PER and DY are 6739.0\%, $741677 \%$ and $34150 \%$ which show more effect on GDP than other tested independent variables and the mean and median values are closer which show that there is reduction in the abnormality of the variables.

From the results in the table above, statistical assumption must be met such as normality test, heteroscedasticity and multicolinearity. The assumption of normality test is confirmed through the Jacque-Bera probability, kurtosis and value of the skewness.

Jacque- Bera is a statistical test that determines whether the series is normally distributed. This statistics measures the difference of the skewness and the kurtosis of the series with those from the normal distribution. The null hypothesis is that the series is normally distributed. Evidently, the Jacque- Bera statistics rejects the null hypothesis of non-normal distribution for GDP, MC, PER, DY, PCI and INF. However, the null hypothesis of non-normal distribution is accepted for interest rate since the probability value for interest rate is greater than 0.05 . Thus, we conclude that PCI is not normally distributed while others are Skewness which is a measure of the shape of the distribution shows that PCI is bell shaped or asymmetric while those of gross domestic product, market capitalization, price earnings ratio, dividend yield, and inflation suggest a long tail to the right since their value is greater than one.

Hence the natural logarithm of the variables are taken normalize the equation (2), then the equation turn to;

$\operatorname{LogGDP}=\beta_{0}+\beta_{1} \operatorname{LogMC}_{t}+\beta_{2} \operatorname{LogPER}_{t}+\beta_{3} \operatorname{LogDY}_{t}+\beta_{4} \operatorname{LogPCI}_{t}+\beta_{5} \operatorname{LogINF}+\mathrm{U}_{\mathrm{t}}$

\section{Tests for Multicollinearity}

Multicollinearity test is used here to ascertain the violation of the assumption of randomness of the explanatory variables of the model. In carrying out the test, we made use of the correlation matrix table. If the pair-wise or zero-order correlation coefficient between explanatory variables is high, say in excess of 0.95 , then multicollinearity is a serious problem (Gujarati, 2003).

\section{CORRELATION MATRIX}

\begin{tabular}{|l|c|c|c|c|c|c|}
\hline & $\begin{array}{c}\text { LOGGD } \\
\text { P }\end{array}$ & LOGNSA & LOGINT & LOGINF & $\begin{array}{c}\text { LOGCB } \\
\text { D }\end{array}$ & $\begin{array}{c}\text { LOGCB } \\
\text { C }\end{array}$ \\
\hline LOGGDP & 1.000000 & 0.916407 & 0.336093 & -0.137713 & 0.980438 & 0.954466 \\
\hline LOGMC & 0.926407 & 1.000000 & 0.260555 & -0.128867 & 0.992775 & 0.909330 \\
\hline LOGPER & 0.336093 & 0.260555 & 1.000000 & 0.437747 & 0.274436 & 0.288928 \\
\hline LOGINF & -0.137713 & -0.128867 & 0.437747 & 1.000000 & -0.135404 & -0.102522 \\
\hline LOGDY & 0.910438 & 0.932775 & 0.274436 & -0.135404 & 1.000000 & 0.960794 \\
\hline LOGPCI & 0.934466 & 0.949330 & 0.288928 & -0.102522 & 0.980794 & 1.000000 \\
\hline
\end{tabular}

\section{Source: E-View 9.0.}


The result of correlation matrix shows evidence of no multicollinearity in the model since none of the partial correlation coefficient or pair-wise correlation is greater than 0.95 .

\section{Tests for Stationarity}

It had been shown in econometric studies (see Engle and Granger, 1987) that most macroeconomic time series are not stationary at levels. This implies that most OLS regressions carried out at levels may not be reliable. Giving this knowledge, testing for stationarity of variables to obtain a more reliable result becomes very essential. This study carried out stationarity test of the variables using Phillip- Perron (PP) Unit Root Test at both intercept with trend, which are reported in the Table below.

\section{Phillip-Perron Unit Root Test}

\begin{tabular}{|c|c|c|c|}
\hline & $1^{\text {st }}$ Difference & Decision & Lag \\
\hline Variable & Intercept with Trend & $1(1)$ & 3 \\
\hline LogGDP & -6.155697 & $1(1)$ & 3 \\
\hline LogMC & -4.464092 & $1(1)$ & 3 \\
\hline LogPER & -4.921903 & $1(1)$ & 3 \\
\hline LogINF & -4.388700 & $1(1)$ & 3 \\
\hline LogDY & -4.360908 & $1(1)$ & 3 \\
\hline LogPCI & -11.39946 & $1(1)$ & 3 \\
\hline \multicolumn{4}{|c|}{ Critical Values } \\
\hline $1 \%$ & -4.148465 & & \\
\hline $5 \%$ & -3.500495 & & \\
\hline $10 \%$ & -3.179617 & & \\
\hline
\end{tabular}

\section{Source: E-View 9.0.}

In this study, the Phillip-Perron (PP) unit root tests were employed to test for the time series properties of the model. The summarized result presented in the table above shows that at various levels of significance $(1 \%, 5 \%$, $10 \%$ ), all the variables were found stationary after differencing once, since the PP values are greater than the critical values in absolute forms. Given the result, we suspected a long run relationship between the dependent and independent variables since they have the same level of integration. So we proceed to test for co-integration in order to ascertain the long run relationship.

\section{Co-Integration Tests}

When a linear combination of variables that are I (1) produces a stationary series, then the variables may need to be co-integrated. This means that a long-run relationship may exist among them, which connotes that they may wander from one another in the short-run but in the long-run they will move together. To establish whether longrun relationship exists among the variables or not, Co-integration test using Johansen's multivariate method and Engle and Granger Test was carried out and reported in table 4.6.1 and 4.6.2 below.

\section{Johansen Co-Integration Test}

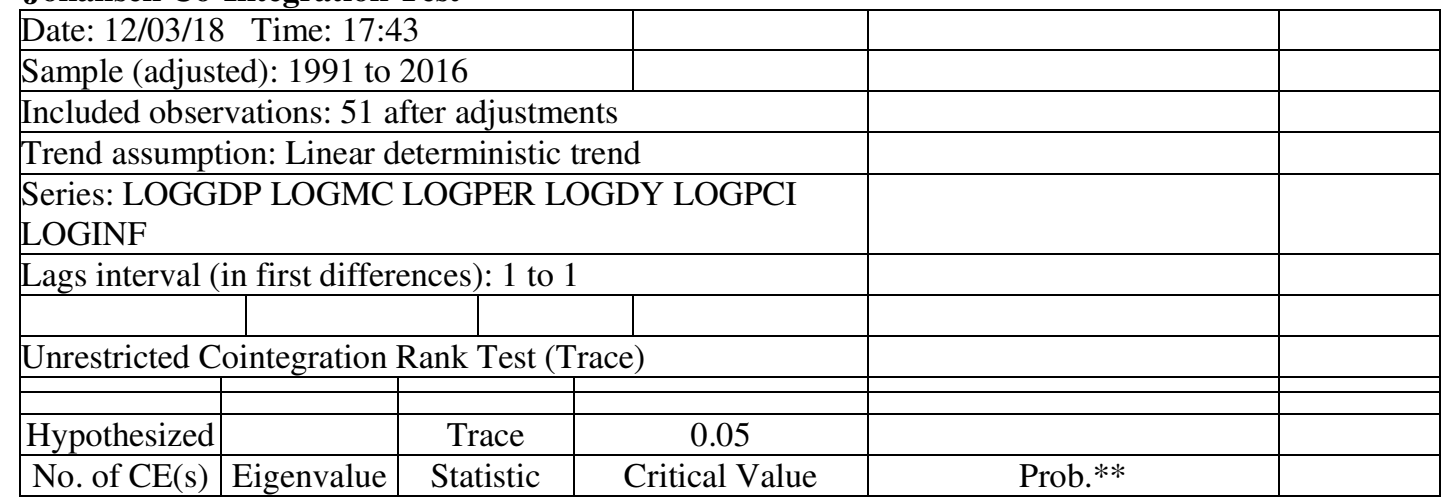




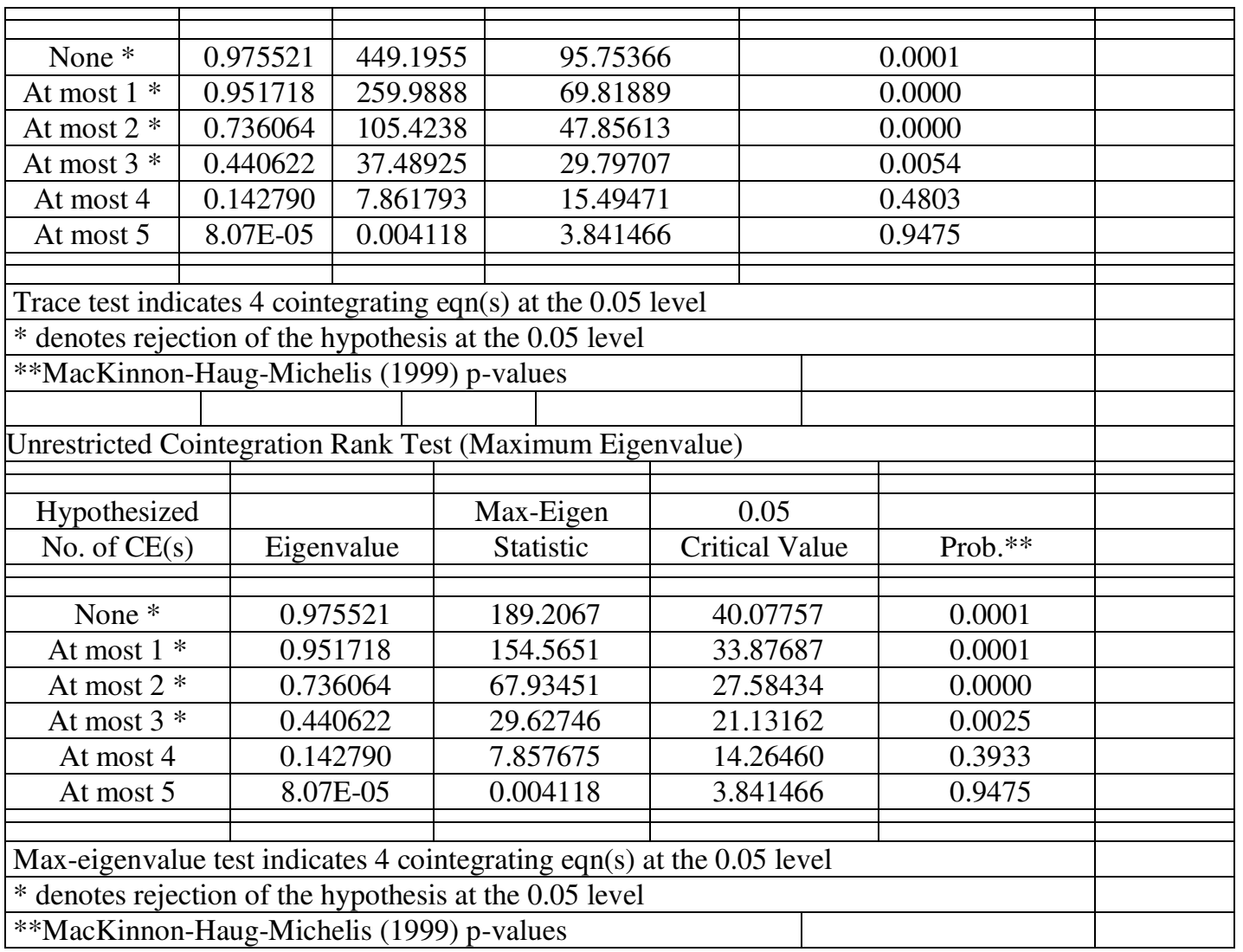

\section{Source: E-View 9.0}

Using the trace likelihood ratio, the results point out that the null hypothesis of no co-integration among the variables is rejected in favor of the alternative hypothesis up to four co-integrating equations at $5 \%$ significant level because the values exceed the critical values. This means there are at least four integrating equations, which implies that a unique long-run relationship exists among the variables and the coefficients of estimated regression can be taken as equilibrium values.

\section{Engle and Granger Co-Integration Test Result}

A necessary but not sufficient condition for co-integration test is that each of the variables must be integrated of the same order and save the residual. The Engle and Granger causality co-integration test were used to test long run relationship among the variables in the study. In order to determine which variable in the model cause other variables granger test will be suggested from the test. The F- statistics is used to reject or accept the null hypothesis of no causation between the variables. When F-statistics is greater than two or the P-value must be less than 0.05 .

\section{Granger Causality Result Dependent Variable and Independent Variables}

\begin{tabular}{|c|c|c|c|}
\hline \multicolumn{4}{|l|}{ Pairwise Granger Causality Tests } \\
\hline \multicolumn{4}{|l|}{ Date: $12 / 03 / 18$ Time: 17:52 } \\
\hline \multicolumn{4}{|l|}{ Sample: 1991 to 2016} \\
\hline \multicolumn{4}{|l|}{ Lags: 2} \\
\hline Null Hypothesis: & Obs & F-Statistic & Prob. \\
\hline LOGMC does not Granger Cause & & & \\
\hline LOGGDP & 51 & 2.83551 & 0.0690 \\
\hline \multicolumn{2}{|c|}{ LOGGDP does not Granger Cause LOGMC } & 26.1242 & 3.E-08 \\
\hline LOGPER does not Granger Cause & 51 & 1.55800 & 0.2215 \\
\hline
\end{tabular}




\begin{tabular}{|c|c|c|c|}
\hline LOGGDP & & & \\
\hline LOGGDP does not Granger Cause LOGPER & & 0.13564 & 0.8735 \\
\hline LOGINF does not Granger Cause & & & \\
\hline LOGGDP & 51 & 0.19307 & 0.8251 \\
\hline LOGGDP does not Granger Cause LOGINF & & 0.34493 & 0.7101 \\
\hline LOGDY does not Granger Cause & & & \\
\hline LOGGDP & 51 & 30.6433 & 3.E-09 \\
\hline LOGGDP does not Granger Cause LOGDY & & 23.6233 & 9.E-08 \\
\hline LOGPCI does not Granger Cause & & & \\
\hline LOGGDP & 51 & 2.27299 & 0.1145 \\
\hline LOGGDP does not Granger Cause LOGPCI & & 17.8656 & 2.E-06 \\
\hline
\end{tabular}

Source: E-View 9.0

From the granger causality result above, there is granger causality of GDP on MC that is gross domestic product granger cause Nigeria national savings and MC does not granger cause GDP which means that gross domestic product can predict market capitalization. This can also be confirmed from the P-value result that the probability value is $(\mathrm{P}<0.05)$. There exist granger causality between both variables (price earnings ratio) PER and gross domestic product (GDP) that any of the two variables can predict each other in the long run since their probability value is less than 5 percent, that future value and outcome of price earnings ratio can predict gross domestic product and vice-versa.

Inflation rate does not granger cause gross domestic product and vice-versa which means that the GDP cannot predict the future direction of inflation rate and also inflation cannot predict GDP, this can also be confirm from the $\mathrm{P}$-value as the $(\mathrm{P}>0.05)$.

There exist granger causality between both variables dividend yield and gross domestic product that any of the two variables can predict each other in the long run since their probability value is less than 5 percent, that future value and outcome of the dividend yield from investment can predict Nigeria economic activities and vice-versa and that the two variables are co-integrated.

Presentation and Interpretation of Regression Result

\begin{tabular}{|c|c|c|c|c|}
\hline \multicolumn{5}{|c|}{ Dependent Variable: LOGGDP } \\
\hline \multicolumn{5}{|c|}{ Method: Least Squares } \\
\hline \multicolumn{5}{|c|}{ Date: $12 / 03 / 18$ Time: 05:15 } \\
\hline \multicolumn{5}{|c|}{ Sample: 1991 to 2016} \\
\hline \multicolumn{5}{|c|}{ Included observations: 53} \\
\hline Variable & Coefficient & Std. Error & $\mathrm{t}$-Statistic & Prob. \\
\hline $\mathrm{C}$ & 452978.2 & 580537.5 & 0.852528 & 0.3457 \\
\hline LOGMC & 1.638564 & 1.540456 & 1.063688 & 0.0929 \\
\hline LOGPER & 113267.0 & 47084.50 & 3.042764 & 0.0038 \\
\hline LOGDY & 19143.32 & 18441.66 & -1.580298 & 0.1207 \\
\hline LOGPCI & 0.283182 & 0.687484 & -0.411910 & 0.6823 \\
\hline LOGINF & -13.54432 & 1.449316 & 6.178386 & 0.8700 \\
\hline R-squared & 0.720448 & Mean dependent & & 5045648 \\
\hline Adjusted R-squared & 0.732304 & S.D. dependent vi & & 10111636 \\
\hline S.E. of regression & 1828400. & Akaike info criter & & 31.78205 \\
\hline Sum squared resid & $1.57 \mathrm{E}+14$ & Schwarz criterion & & 32.00510 \\
\hline Log likelihood & -436.2244 & Hannan-Quinn cr & & 31.86783 \\
\hline F-statistic & 108.6782 & Durbin-Watson st & & 1.750114 \\
\hline Prob(F-statistic) & 0.000000 & & & \\
\hline
\end{tabular}

Source: E-view Version 9.0

From the regression result above, the estimated equation is stated below:

$\operatorname{LogGDP}=452978+1.6386 \mathrm{MC}+1133 \mathrm{PER}+1914 \mathrm{DY}+0.283 \mathrm{PCI}-13.544 \mathrm{INF}$ 
The value of co-efficient of determination or "goodness of fit" ( $\mathrm{R}=0.720448)$ which mean that the variables are closely fitted up to 72 percent while the adjusted co-efficient of determination $\left(\mathrm{R}^{2}=0.732304\right)$ showed that variation noticed in the dependent variable (Gross Domestic Product) is attributed to combine influence of independent variables up to 73 percent while the remaining $27 \%$ is capture by the stochastic term. The value of Durbin-Watson is 1.75 this falls within the determine region and implies that there is absence first order serial autocorrelation among explanatory variables in the model. The F-statistics is used to test for stability in the regression parameter estimate and for rejection or acceptance of the hypotheses formulated in the study. This shows that the F-statistics $>$ F-table at 5 percent, which means that collectively the model is well fitted and stable thus, we compare the calculated $\mathrm{F}^{*}$ statistics with the critical at 5\% level (0.05) at K-1 i.e (6-1=5) and N-K ( 53$6=47$ ) degree of freedom for the model. Where; $K=$ the number of parameter estimated, and $N=$ the number of observed years. The overall regression is highly significant at 5\% level of significance. This suggests that the joint effects of all the included variables are significant.

The coefficients of the independent variables show that from the regression equation above, the regression result shows that Market Capitalization has a positive and significant effect on gross domestic product that is economic growth since the probability value is less than 10 percent. The regression co-efficient shows that price earnings ratio has positive effect and suggested that an increase in price earnings ratio will leads to p6tositive increase in economic growth in Nigeria. capital market and investment which is inconsistence with the result of The coefficients of the independent variables show that all the independent variables are positive and significant except INF (Inflation Rate) which have negative impact. The coefficient of MC (Market Capital= 1.638564) shows that there is positive relationship between economic growth and Market Capitalization. That is one unit increase in MC will lead to 1.64 increases in gdp.

In the same results, the coefficient of PER (price earnings ratio= 113267.0)which show that one unit increase in PER will bring about increase in economic growth. While coefficient of DY (Dividend Yield=19143.32) show that there is positive relationship between the DY and GDP within the period of study. Also coefficient of PCI (Per Capita Income $=0.283182$ ) has positive relationship with economic growth. While coefficient of INF (Inflation Rate=-13.54432) has negative relationship with economic growth. It means one unit increase inflation rate will lead to 13.54 percent decrease in Gross Domestic Product.

\section{Interpretation of Results}

In the results obtained, Nigeria Stock Market activities (as represented by Market capitalization-MC, Price Earnings Ratio-PER and Dividend Yield-DY) has positive influence on economic growth (GDP). The probabilityvalue is also less than 10 percent. Therefore reject the null hypothesis in hypothesis I that Nigeria stock market's activities have not contributed to economy growth Nigeria.

In testing hypothesis II, the coefficient of PCI (Per capita Income representing economic development in Nigeria also show positive correlation and the coefficient also show positive impact with probability less than 10 percent. Inflation rate (representing economic development) has negative effect on Nigerian economic activities within the period of study and the P-value of inflation rate is less than 10 percent critical value which means that inflation rate has impact on economic activities. Therefore reject null hypothesis that Nigerian stock market's activities have no impact on Nigeria economic development. It is thereby established that there Nigerian stock market's activities have impact on Nigeria economic development within the period of study.

The F-Statistics is use to test the hypotheses. If $\mathrm{F}^{*} \mathrm{cal}>\mathrm{F}$-table at $\mathrm{P}>0.05$, we reject the null hypothesis and accept the alternative hypothesis and vice versa. From the statistics table, F $0.05=2.37$. Obviously $\mathrm{F}^{*}>\mathrm{F}_{0.05}$ that is (2.37), this implies that the parameter estimate is statistically significant and stable. This result is consistent with the study conducted by Adelegan, and Radzewicz-Back, (2009). The probability F-Statistics from the regression output also confirm the goodness fit of the model as the Probability F-Statistics value is less than 0.05 that is $(\mathrm{F}-\mathrm{Stat}=0.0000<0.05)$.

\section{Conclusion and Recommendations}

From the analysis above, the study therefore conclude that stock market instruments are the promoter that drives any economy. It was discovered that, there exists a bi-directional relationship between stock market capitalization and its subsequent impact on the economic activities. On the basis of the above findings, Nigerian capital market 
has not fully performed its natural function of funding investment and stimulating growth because the proportion of the market share represented in the national economy is infinitesimal to drive the economy.

\section{Recommendations}

In view of the findings, the following are the suggested recommendations that can help facilitate and deepen the Nigerian capital market activities;

* Improvement in the dealing market capitalization by encouraging more foreign investors to participate in the market, maintain and improve it state of technology like automated trading and settlement practices, electronic fund clearance and eliminate physical transfer of shares.

* Government should place embargo on the funding of development projects by both the public and private sectors through the capital market. Government development project should be at least $70 \%$ funded by funds raised in the market.

* Also, the depth and breadth of the stock market should be expanded to accommodate not only more securities but increase the value of the securities traded in the market.

- Foreign portfolio investment (FPI) and foreign direct investment (FDI) should be vigorously pursued as additional stimulants and propellers of economic growth and development.

\section{REFERENCES}

Adelegan, J., and Radzewicz-Back, B. (2009), What Determines Bond Market Development in Sub-Saharan Africa? IMF Working Paper 09/281

Adelegan, O.J. (2008), Can Regional Cross-listings Accelerate Stock Market Development? Empirical Evidence from Sub-Saharan Africa. IMF Working Paper 08/281.

Andrianaivo, M., and Yartey, C.A (2009), Understanding the Growth of African Financial Markets. IMF Working Paper 09/182.

Arestis, P., Demetriades, P.O., Luintel, K.B (2001), Financial Development and Economic Growth:The Role of Stock Markets. Journal of Money, Credit and Banking, 33(2),16-41.

Ariyo A. and Adelegan O. (2005): Assessing the impact of capital market reforms in Nigeria;. An incremental approach. Paper presented at the 46th Annual Conference of the Nigeria Economic Society in Lagos

Bae, K., Bailey, W., and Mao, C.X. (2006), Stock Market Liberalization and the Information Environment, Journal of International Money and Finance, 25, 404-428.

Baker, H.K. (2016), Trading Location and Liquidity: An analysis of U.S. Dealer and Agency Markets for Common Stocks. Financial Markets, Institutions \& Instruments, 5(4), 1-51.

Baumol, J.W. (1960), The Stock Market and Economic Efficiency. New York: Furham University Press.

Bekaert, G., Harvey, C.R., Lundblad, C. (2001), Does Financial Liberalization Spur Growth?.NBER Working Paper No. 8245.

Bekaert, G., and C. R. Harvey .(2000), Foreign Speculators and Emerging Equity Markets. The Journal of Finance 55, 565-613.

Billmeier, A. and Massa, I. (2007). What Drives Stock Market Development in the Middle East and Central Asia-Institutions, Remittances, or Natural Resources?. IMF Working Paper 07/157

CBN (2000): The Changing Structure of the Nigerian Economy and Implications for Development, Research Department, Lagos.

Central Bank of Nigeria Statistical Bulletin for Several Issues: http:// www.cenbank.org.

Daferighe, E. E. and Aje, S. O. (2009). An Impact Analysis of Real Gross Domestic Product, Inflation and Interest rates on stock prices of quoted companies in Nigeria. International Research Journal of Finance and Economics, Issue 25, pp 53-63.

El-Wassal, K.A. (2005), Understanding the Growth in Emerging Stock Markets. Journal of Emerging Market Finance, 4(3), 227-61.

Engle, R.F., and Victor, K.(1993), Measuring and Testing the impact on Volatility. The Journal of Finance, 48(5), 1749-1778. The Development of Stock Markets: In Search of a Theory

Mockus V.F. and Liu, L. (2012). Macroeconomic Determinants of Stock Market Development. Journal of Applied Economics, 4, 29-59.

Glen, J. (1994), A Introduction to the Microstructure of Emerging Markets. International Finance Corporation Discussion Paper No.2.

Lervine, R. and Zervos, S. (2010). Stock market development and long-run growth. American Economic Review, 88(3), 537-558.

Levine, R. (1991): Stock markets, growth and tax policy, Journal of finance, 46(4), 1445-1465.

Levine, R., Z. (1996): Stock market development and long-run growth. The World Bank Economic Review, 10(3), 323-339. 
Mbat (2001)Mun, A.D., Siong, M.A and Thing, C.A. (2008). Stock market development and long-run growth. The World Bank Economic Review, 10(3), 323-339.

Oke, M. O and Adeusi, S. O (2012). Impact of Capital Market Reforms on Economic Growth: The Nigerian Experience: Journal of Business and Management Research, Vol. 2 (2) PP 20-30.

Okereke-Onyiuke, N (2000). Stock Market Financing Options for Public Projects in Nigeria. The Nigerian Stock Exchange Fact Book, pp. 41 - 49.

Omole, A. S (2007). Stock market development and Nigerian economic growth. Journal of Economic and Allied Fields, 2(2), 116-132.

Onagoruwa, O. (2006): Analysis propose Antidotes to Down Trend in the market. Stock Watch, Vol. 1 (4), pp 3-8.

Osamwonyi, D.G (2005): The Impact of the Nigerian Capital Market on Economic Growth (19902010).International Journal of Developing Societies Vol. 1, No. 1, 2012, 11-19.

Osaze, B.E (1995): Paradigm shift, Misplaced Concreteness and the Nigerian Financial System. InauguralLecture Series, 41 University of Benin pp. 40-41.

Osaze, B.E (2000): The Nigeria Capital Market in the African and Global Financial System. Benin City: BoficConsults Group Limited.

Osuagwu, L. (2003): Research Methodology in Behavioural Science, Lagos: Grey Resources Limited.

Oyefusi S.A. \& Mogbolu R.O. (2003). Nigeria and the Structural Adjustment Programme. In: M.A Iyoha, C.O. Itsede (Eds); Nigerian Economic Structure, Growth and Development, Benin City; Mindex publishing, pp. 387-402.

Samuelson, P. (1965): "Proof that Properly Anticipated Prices -Fluctuation Randomly" Industrial Management Review, 6.

Yesufu T.M. (1996): The Nigerian economy: Growth without development being social sciences for Africa University of Benin, Pp 89-110. 